Preprint. Paper published in 2015 in Tourism Management Volume 50: 1-12

\title{
Valuing Access to Protected Areas in Nepal: The Case of Chitwan National Park
}

\author{
Ram Pandit \\ Corresponding author \\ School of Agricultural and Resource Economics \\ University of Western Australia \\ 35 Stirling Highway \\ Crawley, WA 6009, Australia \\ Phone: +61 864881353 \\ Fax: +6186488 1098 \\ Email: ram.pandit@uwa.edu.au \\ Maheshwar Dhakal \\ Department of National Park and Wildlife Conservation \\ Ministry of Forests and Soil Conservation \\ Babarmahal, Kathmandu, Nepal \\ Phone: +97714227926 \\ Email: maheshwar.dhakal@gmail.com \\ Maksym Polyakov \\ Centre for Environmental Economics and Policy \\ School of Agricultural and Resource Economics \\ University of Western Australia \\ 35 Stirling Highway \\ Crawley, WA 6009, Australia \\ Phone:+61 864885509 \\ Email: maksym.polyakov@uwa.edu.au
}




\section{Highlights}

- We estimated visitors willingness-to-pay (WTP) entrance fee at Nepal's Chitwan National Park.

- We considered three groups of visitors: non-South Asian foreigners, South Asian foreigners, and domestic.

- Mean WTPs are substantially higher (> 159\%) than the current entry fees.

- WTP is positively affected by visit experience and negatively by candidate entry fees.

- At revenue maximising entry fees, park revenue would increase by more than $80 \%$.

- Increased entry fees provide additional revenue for park management and local development. 


\begin{abstract}
This paper investigates the international and domestic visitors' willingness to pay (WTP) an entry fee at Chitwan National Park (CNP) in Nepal, the factors affecting their WTP, and the trade-offs among entry fees, visitation demand and park revenue. Based on the contingent valuation surveys of 222 non-South Asian, 48 South Asian, and 40 domestic visitors, the logit regression results suggest that the visitors have a substantially higher WTP than the current entry fees. Depending on visitor categories, the estimated mean WTP per visitor per day was at least 2.5 times higher than the existing entry fee. The WTP is positively affected by the visitor's CNP experience. The current fees capture only about $21 \%$ of consumer surplus derived from CNP access. Doubling the current entry fees would modestly decrease the number of CNP visitors $(61 \%)$.
\end{abstract}

Keywords: Chitwan National Park, entry fee, mean willingness-to-pay, contingent valuation, non-South Asian, South Asian, domestic visitor, consumer surplus 


\section{Introduction}

Protected areas (PAs) are the cornerstone of global biodiversity conservation (Naughton-Treves, Holland, \& Brandon, 2005; Venter et al., 2014) and the prime destinations for nature-based tourism due to their unique biological, natural and cultural features (Ceballos-Lascurain, 1996; Whitelaw, King, \& Tolkach, 2014). By 2012, a total of 130,709 PAs of various types had been established globally covering $24,236,479 \mathrm{~km}^{2}$ of terrestrial $\left(16,263,609 \mathrm{~km}^{2}\right)$ and marine $\left(8,106,430 \mathrm{~km}^{2}\right.$ ) habitats (IUCN \& UNEP-WCMC, 2012). ${ }^{1}$ They constitute an important sector of the global tourism industry and contribute substantially to local and national economies (Archabald \& Naughton-Treves, 2001; Nyaupane \& Poudel, 2011). The management of PAs, however, is invariably under-funded and their financial self-sufficiency and sustainability remain unclear (Adams et al., 2008; Bovarnick, Baca, Galindo, \& Negret, 2010; Buckley, 2003; IUCN, 2005; Whitelaw et al., 2014).

The entry fees charged on visitors to access PAs can be an important source of revenue for park management and local development (Alpízar, 2006; Dharmaratne, Yee Sang, \& Walling, 2000). The optimal entry fee to access PAs depends on several factors including the purpose of charging the fee, characteristics of the PA, and visitors' willingness-to-pay (WTP $)^{2}$. An entry fee is

\footnotetext{
${ }^{1}$ Only national protected areas with designated establishment date are included. A total of 43,674 national protected areas have been excluded in these figures (IUCN \& UNEP-WCMC, 2012).

${ }^{2}$ If access to natural areas is treated as citizen rights then imposing entry fee on parks brings a philosophical debate, this public goods view of PAs is not covered in this paper (see Laarman \& Gregersen, 1998; Reynisdottir, Song, \& Agrusa, 2008). We take the 'user pay' view because park visitors in Nepal are predominantly international visitors; and the entrance fee collected from these visitors is the important source of park revenue.
} 
intended to capture a fair share of economic value, generate revenue, offset management costs, and reduce visitor congestion (Adams et al., 2008; Laarman \& Gregersen, 1998; Lindberg \& Huber Jr, 1993; Wells, 1993; Whitelaw et al., 2014). In addition, the uniqueness of a PA in terms of its nature-based tourism experience and what it protects can add a scarcity value to the entry fee. For example, the Volcanoes National Park in Rwanda, known as a haven for Mountain Gorilla, charges a whopping US $\$ 750$ for foreign visitors. Similarly, visitors’ WTP, which largely depends on their socio-economic characteristics, would also influence the entry fee (Adams et al., 2008; Alpízar, 2006; Baral, Stern, \& Bhattarai, 2008; Mmopelwa, Kgathi, \& Molefhe, 2007; Ransom \& Mangi, 2010; Reynisdottir et al., 2008).

In developing countries, the PA entry fees paid by visitors are often lower than what they are prepared to pay (Dixon \& Sherman, 1991; Whitelaw et al., 2014). Using example from Nepal, Wells (1993) states that the proportion of economic benefits captured by the host county is lower than the proportion of benefits captured by visitors. Laarman and Gregersen (1998) further, argue that setting an appropriate entry fee for nature-based tourism (including visits to PAs) is a seriously neglected aspect of public policy, creating unintended results where the governments of poor countries subsidize visitors from wealthier countries. Therefore, charging reasonable entry fees to access PAs is important for developing countries, like Nepal, not only to capture an equitable share of the economic benefits generated by the PAs but also to generate revenue to improve park management and to create incentive for conservation among local communities by supporting their local development aspirations.

Starting in 1973, Nepal has established a network of 20 PAs to conserve globally significant biodiversity and natural landscapes (DNPWC, 2012). These PAs cover $34,187 \mathrm{~km}^{2}(23.23 \%$ ) of 
different parts of Nepal. It has adopted a discriminatory entry fee policy based on the PAs location (terai, hill, mountain), type (national park, wildlife reserve, conservation area, hunting reserve), and the visitor category. According to the convention used by the Department of National Park and Wildlife Conservation (hereafter, the Department), the visitors are broadly grouped into three categories, which include domestic visitors and two categories of international visitors. Visitors from Afghanistan, India, Pakistan, Bangladesh, Bhutan, Sri Lanka, and Maldives are classified as South Asian foreign visitors (SAF), while international visitors from other countries are classified as non-South Asian foreign visitors (NSAF). Based on this classification, visitors pay different entry fees to access PAs in Nepal. In 2011, a NSAF visitor paid Nepalese Rupee (NRs) 500 (equivalent to US\$7) ${ }^{4}$, a SAF visitor paid NRs 200 (US\$2.75), and a domestic visitor paid NRs 20 (US\$0.28) as entry fee per day to access Chitwan National Park (CNP). The entry fees charged on domestic visitors are lower than that of other visitor categories partly because domestic visitors pay taxes, which contribute to financing the parks through central budget allocation. In the fiscal year 2009-10, the entry fees collected from all 115,181 visitors contributed two-thirds to the park revenue (US\$842,088), of which the greatest share (US\$556,397 or 92,9\%) was attributed to NSAFs, primarily because of their numbers and higher entry fees (DNPWC, 2010).

\footnotetext{
${ }^{4}$ The average exchange rate (selling rate) during the survey period (16 May to 15 September, 2011): 1 US\$ = NRs 72.46 and 1Euro = NRs $103.41($ Nepal Rastra Bank, 2014).
} 
The entry fees to PAs in Nepal were last revised in 1991 and have remained unchanged despite increased management costs and significant currency devaluation since then. The implications of this stagnation in fees include: increased visitor congestion in easily accessible parks during the peak season (mid-September to mid-May); constrained finances for park management; and limited support for local development to empower participatory conservation envisaged by the buffer zone policy. The Department had proposed to increase the entry fees in 2010, however without success due to the differences between the Department and the tourism entrepreneurs, who feared negative impacts on businesses from increased entry fees. White and Lovett (1999) argue that establishing appropriate entry fees in national parks requires an understanding of visitors' WTP and motivations, which depend on visitors' socio-economic and demographic backgrounds, in addition to the appeal of the particular protected area (Adams et al., 2008; Thur, 2010). These facts were overlooked by both the Department and the tourism entrepreneurs in their deliberations on entry fees.

Earlier WTP studies in developing countries have focused mainly on international visitors and examined their preferences and perceptions regarding entry fees and other park attributes (see Adams et al., 2008; Baral et al., 2008; Chase, Lee, Schulze, \& Anderson, 1998; Mmopelwa et al., 2007; Naidoo \& Adamowicz, 2005). For example, Chase et al. (1998) examine the impact of different entry fees on hypothetical park visitation behaviour among foreign visitors in three Costa Rican parks using a contingent behaviour survey; Naidoo and Adamowicz (2005) estimate the demand for improved biodiversity among foreign visitors in a Ugandan forest park to maximise park revenue using a choice modelling survey; and Mmopelwa et al. (2007) estimate overseas and South African visitors' WTP to visit Moremi Game Reserve in Botswana using a contingent valuation survey under a hypothetical park management scenario of high-cost low- 
volume tourism. In Nepal, Baral et al. (2008) examined the factors affecting foreign visitors' WTP to increase entry fee at Annapurna Conservation Area using a contingent valuation survey. However, these studies have not considered the WTP of different categories of PA visitors. To our knowledge, no other study has yet examined the WTP of all three categories of visitors who pay different entry fees to access PAs in Nepal. We aim to fill this gap in the literature through a unique case study of Chitwan National Park, the most visited park in Nepal.

The purpose of this study is to estimate WTP park entry fee and its determinants among nonSouth Asian, South Asian, and domestic visitors of CNP. We hypothesise that visitors are willing to pay more than the existing entry fee irrespective of the category and their socio-demographic attributes affect their willingness to pay. We estimate consumer surplus ${ }^{5}$ generated by CNP visits and explore alternative entry fees - mean WTP or revenue maximising - and their effect on visitation demand and park revenue by visitor category.

The paper is organized as follows. We introduce the study area in section 2; section 3 presents methods, data and the model; we present the results and discussion in sections 4 and 5; and finally, section 6 concludes the paper.

\footnotetext{
${ }^{5}$ The extra benefit or value a visitor receives from the difference between his or her maximum willingness to pay and the actual amount to be paid (current fee).
} 


\section{Study Site: Chitwan National Park (CNP)}

Chitwan National Park is situated in the South-central Nepal about $200 \mathrm{~km}$ from the capital Kathmandu, covering $932 \mathrm{~km}^{2}$ of the sub-tropical lowlands of the inner Terai (Fig. 1). The park was established in 1973 as the country's first national park to protect globally endangered wildlife, particularly the black one-horned rhinoceros and the royal Bengal tiger. It harbors more than 50 species of mammals, 525 birds, and 55 reptiles and amphibians. These unique features of the park have attracted thousands of visitors each year, making it the most visited park in Nepal. In 1984, it was declared a World Natural Heritage Site by UNESCO for its uniqueness and international significance. Recently, it was rated $19^{\text {th }}$ out of the 35 most amazing national parks on Earth according to an article published in The Huffington Post travel blog (minube, 2014). In $1996,750 \mathrm{~km}^{2}$ of its surrounding area inhabited by local communities was declared a buffer zone $^{6}$ to promote participatory conservation, i.e. conservation that involves local people to design and implement activities in their surrounding by developing partnership with park authority.

[Figure 1 about here]

Parks visitation data indicate that in recent years CNP receives disproportionately high number of visitors compared to other PAs in Nepal (Table 1). For example in 2009-2010 (16 July to 15 July), a total of 381,789 visitors visited 20 PAs, of which 115,181 (30\%) visited CNP. Among

\footnotetext{
${ }^{6}$ An area designated under the buffer zone policy to secure local people's participation in wildlife conservation. The policy allows them to receive up to $50 \%$ of the park revenue as incentive for local development and resource conservation in the area.
} 
the CNP visitors, about 63\% were non-South Asians, $10 \%$ were South Asians and $27 \%$ were domestic visitors (DNPWC, 2010). The high visitor numbers at CNP has resulted in congestion and excessive pressure on park resources, particularly during peak seasons. However, due to the low entry fees, high visitor numbers generated limited revenues for park management and local development. The reason the entry fees are low is that they were not revised since 1991despite inflation and devaluation of Nepalese currency against the US dollar by about 55\% in the meantime. ${ }^{7}$ The entry fees to PAs in Nepal are charged in local currency (NRs), which implicitly subsidizes international visitors if the fee doesn't keep up with the inflation and devaluation of the local currency. Therefore, setting an appropriate entry fees at CNP is important for a number of reasons, which includes reducing congestion and enhancing the visitors' experience; reducing negative externalities such as frequent disturbances to wildlife and park ecosystems, solid waste and water pollution; and increasing revenues that could be used for park management, conservation, and local development activities in the buffer zone.

[Table 1 about here]

\footnotetext{
${ }^{7}$ Currency exchange rate: 1 US $\$=$ NRs 32.00 in 1991 December (Wells, 1993); 1 US $\$=$ NRs 72.46 in 2011 during the survey period (Nepal Rastra Bank, 2014).
} 


\section{Methods}

\subsection{Contingent Valuation}

To estimate visitors' WTP for entry to CNP, we used a contingent valuation (CV) method based on a stated preference approach (Mitchell \& Carson, 1989). The CV directly or indirectly questions respondents about their WTP for an amenity given a set of hypothetical circumstances. The WTP is conditional on these circumstances as well as on respondents' characteristics. Ever since Ciriacy-Wantrup (1947) suggested CV for the first time, it had been widely used in valuation studies but had also been criticised for its shortcomings (Arrow \& Solow, 1993; Carson, Flores, \& Meade, 2001; Diamond \& Hausman, 1994; Lesser, Dodds, \& Zerbe, 1997; Mitchell \& Carson, 1989; Venkatachalam, 2004). The main criticisms of the CV method are that its results suffer from variety of biases (design, operational, hypothetical) as well as from the strategic behaviour (Diamond \& Hausman, 1994; Lesser et al., 1997).

We developed a CV questionnaire that includes 32 questions about visitors' socio-demographic profile, visit purpose and experience, and WTP park entry fee. The WTP question was preceded by an explanatory paragraph that describes the context of the survey, including the current visitation rate at CNP, the Department's plan for changing the entry fee, potential positive impacts of an increased entry fee on visit experience, park management and local development. To minimise hypothetical bias, it was indicated the Department has been seriously considering increasing the entry fee as it has been remained fixed for more than two decades, but undecided on the exact amount of the increase. To prevent respondents' strategic behaviour, it was clearly stated that visitors would not get any compensation to pay an increased entry fee for potential future visits. 
The payment vehicle of the CV survey was "entry fee" for a one day access to CNP. The entry fee was used as a contingency factor for the same level of experience or environmental quality, which is relatively easy to comprehend by visitors. For each visitor category, six candidate entry fees (per-visitor per-day) were selected. In the questionnaire, a visitor was asked to indicate WTP an entry fee randomly selected from the six candidate entry fees, specific to visitor's own category, in a dichotomous choice format. The dichotomous choice format was chosen because it gives a respondent no incentive to not answering truthfully (Mwebaze and Bennett, 2012).To minimise design and operational biases, we closely followed Baral et al. (2008) and established lower range of candidate entry fees based on the dollar value of entry fees when they were last revised in $1991^{8}$. For the NSAF, candidate entry fees ranged from US\$15 to US\$40 at \$5 interval, for SAF candidate entry fees were from US\$7 to US\$20 at $\$ 2.50$ interval, and for the domestic visitors candidate fees were from NRs 100 to NRs 350 at NRs 50 interval. We requested visitors to fill out the questionnaire at the end of their visit, thus helping to relate their visit experience to the candidate entry fee. The WTP question was followed by a follow-up question with multiple choices so that visitors could select the reasons for their acceptance or rejection of the candidate entry fee.

\footnotetext{
${ }^{8}$ The entry fees introduced at CNP in 1991 for NSAF, SAF, and domestic visitors were NRs 500, NRs 200, and NRs 20, respectively. With the exchange rate of $1 \mathrm{USD}=\mathrm{NRs} 32.00$ in 1991 and NRs 72.46 in 2011; US\$15 for NSAF and US\$7.5 for south-Asian are just about equivalent to 1991 entry fee. For domestic visitors starting entry fee was proportionately higher compared to other two categories of visitors, which was based on discussions with CNP park officials, local people and the tourism operators at Sauraha, the main visitor destination at CNP.
} 


\subsection{Data collection}

The sampling frame consisted of three categories of visitors (non-South Asian foreigners, South Asian foreigners, and domestic) who visited CNP during mid-May to mid-September in 2011. Fig. 2 shows the number of CNP visitors in these categories by Nepalese month. We targeted Sauraha, the main visit gateway to CNP that receives about $3 / 4^{\text {th }}$ of the annual park visitors (Chitwan National Park Office, 2012). We also consulted park authorities and the Hotel Association at Sauraha to make sure that the visitor mix in the sample is consistent with the historical patterns of country- or region-specific accommodation preferences of visitors. This consultation helped to identify 20 representative hotels that host mostly visitors from particular countries and regions, including 10 hotels that host mostly and 5 each that host SAF and domestic visitors -

[Figure 2 about here]

A total of 600 questionnaires, including 300 for NSAF and 150 each for South Asian and domestic visitors were distributed to the participating hotels which host about $10.8 \%, 7.9 \%$, and $7.9 \%$ of the total visitors received by CNP in respective categories during the study period. Each participating hotel received 30 questionnaires in equal proportions comprised of a mix of 6 candidate entry fees for a particular visitor category. For example, a hotel identified as an accommodation place for non-South Asians received five questionnaires for each candidate entry fee belonging to this category (i.e. $\$ 15, \$ 20, \$ 25, \$ 30, \$ 35$ and $\$ 40$ ). In each hotel, the hotel manager and reception clerks were briefed about the purpose of the research and the process to follow in distributing the questionnaires to sample visitors. Every $10^{\text {th }}$ visitor who checked-in at the hotel was first provided with a one-page description of the research and the intended use of 
the collected information together with a request for their consent. Those who agreed to participate received a questionnaire with an envelope and were asked to return the completed questionnaire at reception when checking-out.

\subsection{The Model}

Economic theory suggests that a visitor would accept or reject the candidate entry fee specified in a dichotomous choice questionnaire to maximise utility based on the following condition (Hanemann, 1984):

$v(1, I-E F B I D ; \mathbf{X})+\varepsilon_{1} \geq v(0, I-E F B I D ; \mathbf{X})+\varepsilon_{0}$

where $v$ is the indirect utility function, $I$ is the visitors' annual income, EFBID is the candidate entry fee offered, $\mathbf{X}$ is the vector of other explanatory variables affecting the visitors' choice decision, and $\varepsilon_{1}$ and $\varepsilon_{0}$ are identically and independently distributed random errors with zero means and a Gumbel type distributions. Assuming that the utility function is linear, the difference in indirect utility $(\Delta v)$ for accepting or rejecting the candidate entry fee can be described as:

$\Delta v=v(1, I-E F B I D ; \mathbf{X})-v(0, I-E F B I D ; \mathbf{X})+\left(\varepsilon_{1}-\varepsilon_{0}\right)$.

Given the binary choice question for the WTP entry fee (dependent variable), we used logistic regression to determine significant factors affecting visitors' WTP. The standard form of the logistic model relating to the proportion, $P$, of a dependent variable to a vector of the explanatory variable (X) is expressed in (1). As Hanemann (1984) suggests, the econometric model of the 
choice probability that the respondent would be willing to pay the entry fee follows a standard logistic variate:

$P(W T P=Y e s \mid E F B I D, \mathbf{X})=\frac{e^{\alpha+\beta \mathrm{EFBID}+\mathbf{X}^{\prime} \gamma}}{1+e^{\alpha+\beta \mathrm{EFBID}+\mathbf{X}^{\prime} \gamma}}=\frac{1}{1+e^{-\left(\alpha+\beta \mathrm{EFBID}+\mathbf{X}^{\prime} \gamma\right)}}$

where $\alpha$ represents a constant parameter, $\beta$ is the coefficient of the entry fee variable, and $\gamma$ represents the coefficient vector of other explanatory variables $(\mathbf{X})$. The choice probability for accepting the candidate entry fee is modelled as the odds of accepting it, i.e. $\frac{\mathrm{P}\left(\mathrm{WTP}_{\text {Yes }}\right)}{1-\mathrm{P}\left(\mathrm{WTP}_{\text {Yes }}\right)}$. The logit transformation of the probability of accepting the fee then becomes $\mathrm{Ln}\left|\frac{\mathrm{P}\left(\mathrm{WTP}_{\text {Yes }}\right)}{1-\mathrm{P}\left(\mathrm{WTP}_{\text {Yes }}\right)}\right|$, which is related to the explanatory variables and the error $\mu$ by the linear regression of the form:

$\operatorname{Ln}\left(\frac{P_{i}\left(W T P_{Y e s}\right)}{1-P_{i}\left(W T P_{Y e s}\right)}\right)=\alpha+\beta E F B I D+\mathbf{X}^{\prime} \gamma+\mu$,

and in terms of individual variables:

$$
\begin{gathered}
\operatorname{Ln}\left(\frac{P_{i}\left(W T P_{\text {Yes }}\right)}{1-P_{i}\left(W T P_{\text {Yes }}\right)}\right)=\alpha+\beta E F B I D_{i}+\gamma_{1} A G E_{i}+\gamma_{2} G_{i}+\gamma_{3} M_{i}+\gamma_{4} E D U_{i}+ \\
\gamma_{5} \operatorname{CNPEXP}_{i}+\gamma_{6} \text { VISOTH }_{i}+\gamma_{7} \text { ENVCON }_{i}+\mu_{i}
\end{gathered}
$$

In addition to the candidate entry fee, visitors' WTP is affected by socio-demographic and site specific variables (see Alpízar, 2006; Baral et al., 2008; Mmopelwa et al., 2007; Reynisdottir et al., 2008; Walpole, Goodwin, \& Ward, 2001). The explanatory variables (X) included in the model are: age, gender (GEN), education (EDU), membership to environmental organizations (MEM), CNP visit experience (CNPEXP), visits to other parks in Nepal (VISOTH), and a score 
of visitors' environmental concerns at CNP (ENVCON). We excluded the income variable in the model following Hanemann (1984), also applied by Baral et al. (2008) in the similar context of the present study, who suggests that the discrete choice probabilities, $\mathrm{P}(\mathrm{WTP}$ Yes $)$, are independent of individual income in the utility maximization model. In estimating the WTP for domestic visitors, prior visit to other parks was excluded from the model because domestic visitors, unlike international visitors, did not visit other parks prior to their visit to CNP.

There are mixed results in the literature on how age and gender affect visitors' WTP park entry fee. Some researchers (Baral et al., 2008; Mmopelwa et al., 2007) found that visitor's age has no effect on WTP, while others (Baral et al., 2008; Bowker, Cordell, \& Johnson, 1999; Mmopelwa et al., 2007; Reynisdottir et al., 2008) found that WTP decreases with age. Gender has no effect on willingness of visitors paying the fee (Baral et al., 2008; Herath \& Kennedy, 2004; Mmopelwa et al., 2007; Reynisdottir et al., 2008; Tapsuwan, Burton, \& Perriam, 2010). Therefore, we have no a priori expectation on how age and gender affect the probability of visitors accepting the candidate entry fee at CNP.

We expect that the affiliation with environmental organisations, higher education levels, and better visit experience increase the probability of accepting the candidate entry fee. We do not have an a priori expectation about the effect of visit to other protected areas in Nepal on WTP for the following reasons. On the one hand, CNP is a protected area of international significance, a world heritage site that harbors unique charismatic wildlife such as black one horned rhinoceros, suggesting that visit to other protected areas would not diminish visitors' WTP. On the other hand, other protected areas in the same ecological zone could act as substitute for some visitors, which could diminish the WTP entry fee to access CNP. We expect that concerns about 
environmental conditions at CNP (solid waste pollution, water pollution and disturbance to wildlife), would negatively affect the WTP. Finally, we expect that the WTP candidate entry fee is inversely related to the bid amount offered.

\subsection{Data Analysis}

Visitors' responses to each question in the questionnaire were first coded depending on the nature of the question and answer options. Responses to binary choice questions, such as WTP entry fee, AGE, GEN, MEM, VISOTH were coded 0 or 1 , while the responses to the questions with Likert-scale type answer, were coded using 5-point scale $(1=$ strongly disagree, $2=$ disagree, 3 = neither agree nor disagree, $4=$ agree and $5=$ strongly agree). ENVCON is an index variable developed by summing visitors' perception of wildlife disturbance, solid waste and water pollution in and around CNP using 5-point scale. The summated score, which could range from 3 to 15 , was tested for its reliability using Cronbach alpha $(\alpha=0.70)$. Detail descriptions of the model variables used in the analyses, their coding and summary statistics are presented in Table 2.

[Table 2 about here]

To determine the factors influencing visitors' WTP candidate entry fees, we analysed data using the logit regression (3) in R statistical package (R Development Core Team, 2011). For each visitor category, the mean and median WTPs (Eqs. 4 and 5) were derived from the sample means and medians of the variables and the estimated parameters of the model (3) following Hanemann (1989). 


$$
\begin{gathered}
W T P_{\text {median }}=\frac{-(\alpha+\overline{\mathbf{X}} \gamma)}{\beta}=\frac{(\alpha+\overline{\mathbf{X}} \gamma)}{|\beta|} \\
W T P_{\text {mean }}=\frac{1}{|\beta|} * \ln [1+\exp (\alpha+\overline{\mathbf{X}} \gamma)]
\end{gathered}
$$

The value of CNP access was calculated as a consumer surplus using mean WTP, annual number of visitors (16 July 2009 to 15 July 2010), and the average number of days spent at CNP by the visitors in each visitor category. The effect of charging higher entry fees on CNP visitation and revenues were estimated based on 2009-2010 visitor numbers and proportion of visitors that would have visited CNP if they had to pay the increased entry fees.

\section{Results}

\subsection{Sample characteristics}

Of the 300 NSAF visitors participated in the survey, only $234(78 \%)$ returned the questionnaires, 226 of which provided complete responses for model variables. Four of the respondents visited CNP for the research purposes and spent 10 to 57 days at CNP. We excluded their responses from the analysis reducing the sample size to 222 . About $95 \%$ of the 222 NSAF visitors indicated that the CNP visit was a part of their holiday travel. For $70 \%$ of them, the most influential factor that motivated the visit to CNP was its wildlife. Two-third of the visitors had organised their visit through a travel agency and about $76 \%$ hired a guide to explore the park. Each visitor spent on average 2.64 days at CNP, which is about $10.5 \%$ of their time spent in Nepal. Visitors from 28 NSAF countries were sampled, with top five countries being the UK (18\%), the USA (16.7\%), France (8.6\%), Spain (8.1\%), and Canada (6.3\%). 
About $62 \%$ of the NSAF visitors were female, $22.5 \%$ were members of an environmental organisation, $98.2 \%$ were new to CNP and about $16.7 \%$ had visited another protected area in Nepal prior to CNP visit (mostly the Annapurna Conservation Area) (Table 2). The average age of a visitor was 31 years with a Bachelor's degree being the median education. On average, they had a highly positive CNP visit experience ( 8.33 out of 10 ), but they were somewhat concerned with the CNP environment (i.e. solid waste pollution, water pollution, and wildlife disturbance) with a score of 9.75 out of 15 (Table 2).

Of the 150 questionnaires distributed to SAF visitors, 56 were returned with only 48 had responses for most of the questions. The CNP visit was exclusively a holiday trip for all visitors in this category and for about $90 \%$ it was their first visit. For $75 \%$ of these visitors, wildlife was the main motivating factor and about $12.5 \%$ of them had visited another protected area in Nepal prior to visiting CNP. About $88 \%$ of these visitors hired a guide at CNP but only $36 \%$ organised their visit through a travel agency. Most of these visitors were from India (71\%) followed by Sri Lanka (17\%). On average, each visitor spent about 2.65 days at CNP. Compared to NSAF visitors, among SAF visitors there were fewer females (35.5\%), but equal proportion of visitors affiliated with environmental organisations (23\%). On average, SAF visitors were older (37 years), showing a higher concern for CNP environment (11), but had lower CNP experience rating (7.31) comparing to NSAF visitors (Table 2).

Among the domestic visitors, only 52 out of 150 returned the questionnaire with only 40 questionnaires containing responses for model variables. Key features of the domestic visitors included: $60 \%$ were males, $87.5 \%$ were on holiday, $80 \%$ were motivated to visit CNP because of wildlife, $70 \%$ were first-time visitors and $62.5 \%$ hired a guide. The average age of the domestic 
visitors was about 32.8 years and they spent on average about 2.82 days at CNP. Among domestic visitors, the CNP visit experience rating was 7.9, which is slightly higher than the average experience of SAF, and their environmental concern score was higher (12.7) than that of other visitor categories (Table 2).

\subsection{Visitors' perception of current entry fee and willingness to pay candidate entry fee}

We asked the visitors to indicate their perception of the current entry fee (i.e. NRs $500(\approx$ US\$7) for NSAF visitors, NRs $200(\approx$ US\$2.75) for SAF visitors, and NRs $20(\approx$ US\$0.28) for domestic visitors) on a scale of 1 (very low) to 5 (very high) prior to asking the 'WTP' question. Only about $30 \%$ of the NSAF visitors perceived the current fee as low or very low while about twothirds indicated it is just right and about $5 \%$ indicated it is high or very high. Among SAF visitors, about $41.7 \%$ perceived the current entry fee as too low (10.4\%) or low (31.3\%), about half indicated it is just right, and the remainder indicated it is high (8.3\%). However, among domestic visitors, more than two-thirds (70\%) perceived the current entry fee as very low or low, and none indicated it is high or very high. The correlation between visitors' perception of current

entry fee and their willingness to pay candidate entry fee was negative and highly significant for all visitor categories, indicating that those who perceived that the current entry fee is too low or low were willing to pay the candidate entry fee they were offered. The magnitude and strength of the correlation was highest for domestic visitors $(r=-0.582, \mathrm{p}<0.001)$ followed by SAF $(r=-$ 0.523, $\mathrm{p}<0.001)$ and NSAF $(\mathrm{r}=-0.239, \mathrm{p}<0.001)$.

Before responding to the WTP question containing one of the six candidate entry fees, visitors were informed about the reasons behind Department's effort to increase the entry fee, which included no change in fee for over two decades, increased park management costs, and changed 
policy context (buffer zone policy). Visitors were also informed about the Department's effort to seek their views on how much they are willing to pay if they were to visit the park in the future based on the current visit experience. The emphasis on visit experience was important for this research as we were presenting a realistic scenario of fee increase but no specific hypothetical improvement in visit conditions.

\subsection{Visitors' willingness to pay candidate entry fee}

Table 3 presents the response profile of six candidate entry fees by visitor category and the observed and predicted proportions of visitors accepting offered fees. As expected, there is a near perfect negative correlation between the candidate entry fee and the observed probability of its acceptance (Pearson r - 0.950 for NSAF, -0.967 for SAF, and -0.951 for domestic visitors).

[Table 3 about here]

Table 4 presents results of the logit regression (3) of respondents' willingness to pay candidate entry fee by visitor category. Consistent with expectations, the bid value has statistically significant negative effect on WTP for all visitors' categories. The CNP visit experience has statistically significant positive effect on WTP for all visitors' categories as well indicating that visitors are willing to pay more if they had better experience of visiting the park. Another three predictors, namely membership in an environmental organisation, education, and the environmental concern score affect WTP of NSAF visitors. The visitors of this category that are affiliated with environmental organisation or having higher education level are willing to pay higher entry fee, while those concerned with the status of CNP environment are not willing to pay high fees. Our results do not support gender or age affecting WTP of NSAF visitors, 
however gender affects the WTP of the SAF visitors with males willing to pay higher fees, while age affects the WTP of domestic visitors with older people willing to pay more.

[Table 4 about here]

Visitors in each category received only one candidate entry fee out of possible six for their category and expressed WTP to this fee. For example, the possible entry fee that a SAF visitor could have received include US $\$ 2.75$, US $\$ 7.5$, US $\$ 10$, US $\$ 12.5$, US $\$ 15$, US $\$ 17.5$ or US $\$ 20$. The visitors were asked to provide reasons for their choice (accepting or rejecting the candidate fee) in the follow-up question. Only about $35 \%$ of the NSAF visitors answered the follow-up question with much lower response rate in two other visitors' categories, therefore we only analyse responses of the NSAF visitors. The reasons for acceptance or rejection of the offered entry fee are varied and summarised in Table 5 by the frequency of occurrence. In total, about equal number of reasons were cited in favour (96) or against (97) the offered entry fee. The main reasons for accepting the offered fee include a wish to support conservation activities in the park and local development activities in the surrounding areas and a desire to protect the unique wildlife of CNP (Table 5). The most common reasons for rejecting the offered fee include the inability of respondents' to afford it, poor management of the park, and lack of adequate amenities in the park (Table 5).

[Table 5 about here]

Using regression results (Table 4), we estimated probabilities of WTP, visitor numbers, and park revenues for each of the visitors categories for their corresponding ranges of candidate entry fees, as well as visitor categories median (3) and mean (4) WTP (Table 6). The median WTPs 
are US\$16.62, US\$14.25, and US\$2.70 (NRs 196) for NSAF, SAF, and domestic visitors, respectively, whereas mean WTPs are slightly higher for NSAF visitors (US\$18.19), but are similar to the median WTP for both SAF and domestic visitors.

[Table 6 about here]

\section{Discussion}

\subsection{WTP and Consumer surplus}

Our results suggest that, on average, visitors are willing to pay substantially higher entry fee than the current fee to access CNP. The mean WTPs were $159 \%, 418 \%$, and $864 \%$ higher than the current entry fee for NSAF (US\$7), SAF (US\$2.75) and domestic (US\$0.28) visitors. Our finding regarding the WTP of NSAF visitors is consistent with the findings of other studies from different parts of the world indicating that international PA visitors were willing to pay more than they were actually paying to access protected areas (Baral et al., 2008; Mmopelwa et al., 2007; Reynisdottir et al., 2008; Walpole et al., 2001; Whitelaw et al., 2014). With particular reference to Nepal's Annapurna Conservation Area, Baral et al. (2008) estimated that the mean WTP of international visitors was $156 \%$ higher than the prevailing fee of US\$27 per day. The substantially higher mean WTPs among SAF and domestic visitors suggest that at the current fee levels, consumer surpluses from the CNP access are proportionately higher for these visitors than the consumer surplus of NSAF visitors, which is an interesting finding. Given a very small entry 
fee charged on domestic visitors and substantial increase in per capita income ${ }^{11}$ between 1991 and 2011, the significantly higher WTP among domestic visitors is not entirely surprising.

The factors affecting visitor's WTP the park entry fee at CNP are consistent with the earlier findings from Nepal and elsewhere (Adams et al., 2008; Baral et al., 2008; Mmopelwa et al., 2007; Reynisdottir et al., 2008; Thur, 2010) with some variations among visitor categories. Similarly to earlier studies, WTP of NSAF visitors is affected by the bid value, visit experience, environmental concerns, membership in environmental organisations, and education. However, our results do not confirm statistically significant effect of visitor specific factors such as age and gender on WTP of the NSAF visitors. Similar findings are reported by Baral et al. (2008) for Nepal and by Mmopela et al. (2007) for Botswana. Among the SAF visitors, males willing to pay higher entry fee. For the domestic visitors, we found that older visitors demonstrate higher WTP entry fee. The gender and age had mixed influence on visitor's WTP to access PAs in the literature (Baral et al., 2008; Bowker et al., 1999; Herath \& Kennedy, 2004; Mmopelwa et al., 2007; Tapsuwan et al., 2010).

The mean WTP represents the WTP of an average visitor; but for individual visitors, the WTP could vary depending on their attributes and responses to questions represented by model variables. For example, the mean WTP of the NSAF visitors is US\$18.9, however, the mean WTP of the NSAF visitors affiliated with environmental organisations is US\$29, while for the

\footnotetext{
${ }^{11}$ Per capita income in Nepal increased from US\$211 in 1991 to US\$694 in 2011, a 229\% increase (World Bank, 2014).
} 
NSAF visitors who are not affiliated with environmental organisations, it is US\$13. Similarly, a NSAF with a very good visit experience (10 out of 10 ) is willing to pay US\$24.16. For a visitor who is highly concerned with environmental conditions at CNP (15 out of 15), the mean WTP drops to US\$9.86, while a visitor who is least concerned with the CNP environment is willing to pay US\$25.31 for entry fee. The maximum WTP of a SAF visitor for a very good visit experience is about US\$27.37. A SAF male visitor is willing to pay US\$17.25 as entry fee to access CNP compared to a female visitor (US\$8.80). In contrast, the maximum WTP of a domestic visitor with a very good visit experience is only about US\$3.70 (NRs 268).

The consumer surplus generated by CNP access is about US\$11.19, US\$11.50, and US\$2.42 (NRs 176) per person per day for the NSAF, SAF, and domestic visitors, respectively. The visitors of these groups spent at CNP on average 2.64, 2.65, and 2.82 days, respectively. Based on the number of visitors at CNP between 16 July 2009 and 15 July 2010 (Table 1), the mean number of days spent at CNP and the mean WTP, the annual consumer surplus derived ${ }^{12}$ from accessing CNP was about US\$2,155,739, US\$332,147 and US\$214,453 for NSAF, SAF, and domestic visitors, respectively. Together the annual consumer surplus generated by CNP visits was about US\$2,702,339.

Meanwhile, the annual park revenue from entry fees in 2009-2010 was NRs 40,316,520 (US\$556,397), which is only about $21 \%$ of the annual consumer surplus. This indicates that most

\footnotetext{
${ }^{12}$ It is derived by multiplying the mean WTP, mean number of days at CNP and total visitors in 2009-2010 for each visitor category.
} 
of the economic benefits from CNP visits have been captured by the visitors while the costs of conserving wildlife and managing the park have been shared by the Department and the local communities. This is similar to the situation with dragon tourism in Indonesia described by Walpole and Goodwin (2000), This suggests that there is a scope to shift some of the consumer surplus to park revenue through increased entry fees. Of the NRs 30,775,000 (US\$424,717) annual budget of CNP in 2009-2010, only $11.81 \%$ was allocated to development activities, while the rest went to regular expenditure (DNPWC, 2010), such as staff salary and patrolling, indicating limited financial resource to initiate new conservation programs or development activities in the park. Additional revenue from increased entry fees would provide resource to the Department and the local communities to initiate such programs or to effectively implement ongoing programs. It could also be used in environmental management at CNP (such as solid waste/litter, water pollution, wildlife disturbance issues). Half of the increased revenue would go to the local communities, as per the buffer zone management policy, which could be used in development and conservation activities that would result in a stronger local support for biodiversity conservation in and around the park (Wells \& McShane, 2004).

\subsection{Entry fee, park visitation and revenue}

The analyses presented in Table 6 and in Fig. 3 suggest that there are trade-offs between entry fee, visitation demand and park revenue by visitor category. Graphs in Fig. 3 indicate two trends: a negative correlation between entry fee and visitor numbers and an inverted U-shaped relationship between entry fee and revenue. The negative correlations between entry fee and visitor numbers are almost perfect: $-0.997,-0.970$ and -0.976 , for NSAF, SAF and domestic visitors, respectively. For the NSAF visitors, the revenue peaks when the entry fee is higher then 
mean WTP, while for SAF and domestic visitors, the maximum revenue is achieved at the entry fee levels that are lower than mean WTPs (Fig. 3). If the entry fees were set at the mean WTP levels, the numbers of NSAF, SAF, and domestic visitors would decrease by, respectively, $31 \%$, $48 \%$, and $49 \%$, while revenues collected from these visitors categories would increase by, respectively, $77 \%, 170 \%$, and $397 \%$ (Table 6). If the entry fees per visitor per day were set at the revenue maximisation levels, which are US\$21 for NSAF, US\$11.75 for SAF, and US\$2.14 (NRs 155) for domestic visitors, the visitor numbers would decrease, respectively, by 40\%, 30\%, and $26 \%$, while the revenues would increase, respectively, by $80 \%, 197 \%$, and $477 \%$ (Table 6 , Fig. 3).

However, given the sizable decrease in visitor numbers when fees are set at either at the mean WTP levels or at the revenue maximisation level, as well as failed past attempts to increase the entry fee by the Department, increasing of entry fees alone would be economically unattractive for the local businesses and tour operators and practically difficult for the Department to implement. Thus in revising the entry fees, complementary strategies need to be explored to support the local businesses and tourism operators. Such strategies could include training and support to minimise costs of their tour operations, particularly for recreational activities, such as elephant safari, jungle drive, local cultural show, or to diversify the portfolio of tourism activities by including new activities, such as home stay, which potentially increase visitors' stay at CNP thereby minimising the impact on local businesses and tour operators.

[Figure 3 about here]

The increase of entry fee to the revenue maximising level could be a tool to reduce visitor congestion and lessen the pressure on CNP resources. The park officials' observations and the 
recent visit statistics suggest that visitor congestion is one of the factors compromising visit experience during the peak season (mid-September to mid-May), when CNP receives about $73 \%$ of its annual visitors (i.e. Table 1 totals for 2009-2010 compared with Fig. 2 total). Coupled with the efforts to spread park visitation, increased entry fee at CNP should be linked to entry the fees charged by other parks (e.g., other parks fees should be lower than the fees at the CNP) to create incentives for visitors to visit other parks, such as Parsa Wildlife Reserve, which is adjacent to the CNP, or Bardia National Park, which is a close substitute. In the long run, this would increase the revenues of other parks and offer more equitable sharing of economic benefits to local communities while not affecting total visitors numbers. Interestingly, parks with unique natural environments and international fame elsewhere charge substantially higher entry fees, for example, US\$100 in Galapagos National Park, Ecuador and US\$750 in Volcanoes National Park, Rwanda, suggesting that for the parks with no close substitutes, an increased entry fee would not necessarily reduce the number of park visitors. This may, in fact, be the case at CNP given its international significance, which needs to be examined in the future while evaluating the impact of revised entry fees.

\subsection{Limitations and further research}

This study has a number of limitations, which, we believe, do not affect validity of its conclusions. Firstly, we conducted a post-visit survey during the off-season when visitors' pressure on park resources was at minimum. During off-season, the ecotourism facilities and the natural attraction of CNP could be less than optimal for the tourism and our sample visitors may not therefore be wholly representative of the top-end visitors with high purchasing power who visit CNP during peak-season. Therefore, the calculated visitors' WTP entry fee may be 
underestimated. Secondly, because of the post-visit survey based on visit experience, for many visitors this might be a once-in-a life time experience that could introduce bias on their WTP for hypothetical future visit. But we believe that the potential bias introduced from this situation could go in either direction (i.e. some visitors might overstate while others might understate their WTPs) and on average likely to be cancelled out. Thirdly, we did not consider the recreational fees paid by visitors for the various activities they participated in. These fees could potentially interact with the entry fee when the visitor answered the WTP question. Finally, the questionnaires were in English language, which could have introduced some limitations on survey participants as the proficiency of English varies among visitors both for NSAF and SAF. We do not have any information on visitors who refused to participate in the survey because of various reasons including language. Thus, some cautions should be used in generalising the results.

Several interesting questions are left unanswered in this paper. They could form the basis for future WTP studies which would examine: i) seasonal effect on WTP and potential interaction of entry fee with various types of recreational fees, ii) differentiated entry fees by season and by parks, iii) interactions between visitor experience, infrastructure quality and visitor numbers, and iv) strategic visitor management aim of the park and park revenue.

\section{Conclusions}

Our findings suggest that the mean WTPs entry fees to access CNP are US\$18.19 for NSAF, US\$14.25 for SAF, and US\$2.7 (NRs 196) for domestic visitors, which are considerably higher than the current entry fees to access CNP. Given that the entry fees remained unchanged for over two decades, the revision of the entry fees at CNP is desirable and timely. To capture a fair share 
of the economic benefits generated by CNP, it is recommended that the current entry fees should be at least doubled. Fees can be increased up to the revenue maximising level, i.e. US\$21 (NRs 1520) for NSAF, US\$11.75 (NRs 850) for SAF and US\$2.14 (NRs 155) for domestic visitors, if the Department considers the real value of entry fees in 1991 and 2011 with some cautions and provisions of complementary strategies to support local businesses and tour operators.

Among the factors affecting visitors WTP, the candidate entry fee and the visit experience appeared to be the most consistent factors for all visitors. Education, membership to environmental organisation, and environmental concerns only influence the WTP of NSAF visitors, whereas visitor's gender and age influence the WTP of only SAF and domestic visitors, respectively. Therefore, the Department and tourism entrepreneurs at CNP should focus on activities that enhance visitor's experience at CNP. To this end, it is advisable that some portion of the revenue generated from increased entry fees should be used to improve tourism infrastructure and environmental management at CNP.

Given the significance of NSAF visitors to CNP revenue, charging them optimal entry fee is important to maximise park revenue and also to move towards financial self-sufficiency for conservation and development activities in and around the park. On the other hand, our finding on proportionately higher WTP of domestic visitors suggests that future PA-specific tourism studies in developing countries or similar context elsewhere should also look beyond the usual focus on international visitors. This is particularly relevant in the context of increasing domestic tourism in developing countries (Boakye, Annim, \& Dasmani, 2013; Skanavis \& Sakellari, 2011; Wen, 1997) and its potential contribution to economic development. 
Our findings provide case-specific empirical evidence on visitors WTP to access a national park. But the findings potentially hint at the need to revise the entry fees of other protected areas in Nepal. One of the implications of revised (i.e. increased) entry fee would be reducing financial dependency of the Department on foreign donors for biodiversity conservation. From park management point of view, the Department should review its PA entry fee policy periodically, preferably coinciding with 5-year Development Plan of the Nepalese government to maintain a balance between entry fees, visitor numbers and associated impacts on park resources.

Finally, given the focus on tourism for economic development and protected area being one of the main tourism destinations in Nepal, the main finding of this study is closely linked to the conservation for local development policy of the government, i.e. the buffer zone management policy. This policy provides incentives for conservation through revenue sharing with local communities, and the increased entry fee would provide additional resources to these communities for their conservation and development efforts.

\section{Acknowledgements}

We are thankful to the visitors of CNP who took time to fill out the questionnaire and provided their perspectives. We also appreciate the managers and clerks of the 15 hotels who helped to distribute the questionnaires and collect the completed surveys. We thank Assistant Warden Mr. Lal Bahadur Bhandari for his cooperation and coordination in implementing the survey. Finally, we thank Ms Simone Pandit and Mrs Caroline Mitchell for editing the earlier versions of the manuscript and anonymous reviewers for providing valuable suggestions and comments to improve the paper. 


\section{References}

Adams, C., Seroa da Motta, R., Ortiz, R. A., Reid, J., Ebersbach Aznar, C., \& de Almeida Sinisgalli, P. A. (2008). The use of contingent valuation for evaluating protected areas in the developing world: Economic valuation of Morro do Diabo State Park, Atlantic Rainforest, São Paulo State (Brazil). Ecological Economics, 66(2-3), 359-370. doi: 10.1016/j.ecolecon.2007.09.008

Alpízar, F. (2006). The pricing of protected areas in nature-based tourism: A local perspective. Ecological Economics, 56(2), 294-307. doi: 10.1016/j.ecolecon.2005.02.005

Archabald, K., \& Naughton-Treves, L. (2001). Tourism revenue-sharing around national parks in Western Uganda: Early efforts to identify and reward local communities. Environmental Conservation, 28(2), 135-149. doi: 10.1017/S0376892901000145

Arrow, K., \& Solow, R. (1993). Report of the NOAA panel on contingent valuation. Federal Register, 58(10), 4601-4614.

Baral, N., Stern, M. J., \& Bhattarai, R. (2008). Contingent valuation of ecotourism in Annapurna conservation area, Nepal: Implications for sustainable park finance and local development. Ecological Economics, 66(2-3), 218-227. doi: 10.1016/j.ecolecon.2008.02.004

Boakye, K. A. A., Annim, S. K., \& Dasmani, I. (2013). An econometric analysis of internal travel patterns in Ghana and the implications for domestic tourism. Tourism Economics, 19(5), 1155-1171. doi: 10.5367/te.2013.0245

Bovarnick, A., Baca, J. F., Galindo, J., \& Negret, H. (2010). Financial Sustainability of Protected Areas in Latin America and the Caribbean: Investment Policy Guidance. New York: United Nations Development Programme (UNDP) and The Nature Conservancy (TNC).

Bowker, J. M., Cordell, H. K., \& Johnson, C. Y. (1999). User Fees for Recreation Services on Public Lands: A National Assessment. Journal of Park and Recreation Administration, 17(3), 1-14.

Buckley, R. (2003). Pay to play in parks: An Australian policy perspective on visitor fees in public protected areas. Journal of Sustainable Tourism, 11(1), 56-73.

Carson, R. T., Flores, N. E., \& Meade, N. F. (2001). Contingent valuation: Controversies and evidence. Environmental and Resource Economics, 19(2), 173-210. 
Ceballos-Lascurain, H. (1996). Tourism, Ecotourism, and Protected Areas: The State of Naturebased Tourism around the World and Guidelines for Its Development: IUCN.

Chase, L. C., Lee, D. R., Schulze, W. D., \& Anderson, D. J. (1998). Ecotourism demand and differential pricing of national park access in Costa Rica. Land Economics, 74(4), 466482.

Chitwan National Park Office. (2012). Chitwan National Park: Annual Progress Report 20112012 (2068/069 BS) (pp. 46). Kasara, Chitwan: Chitwan National Park.

Ciriacy-Wantrup, S. V. (1947). Capital Returns from Soil-Conservation Practices. Journal of Farm Economics, 29(4), 1181-1196. doi: 10.2307/1232747

Dharmaratne, G. S., Yee Sang, F., \& Walling, L. J. (2000). Tourism potentials for financing protected areas. Annals of Tourism Research, 27(3), 590-610. doi: 10.1016/S01607383(99)00109-7

Diamond, P. A., \& Hausman, J. A. (1994). Contingent valuation: Is some number better than no number? The Journal of Economic Perspectives, 8(4), 45-64.

Dixon, J. A., \& Sherman, P. B. (1991). Economics of protected areas. Ambio, 20(2), 68-74.

DNPWC. (2008). Annual Reports 2007-2008. Kathmandu, Nepal: Ministry of Forests and Soil Conservation, Department of National Parks and Wildlife Conservation (DNPWC).

DNPWC. (2009). Annual Reports 2008-2009. Kathmandu, Nepal: Ministry of Forests and Soil Conservation, Department of National Parks and Wildlife Conservation (DNPWC).

DNPWC. (2010). Annual Reports 2009-2010. Kathmandu, Nepal: Ministry of Forests and Soil Conservation, Department of National Parks and Wildlife Conservation (DNPWC).

DNPWC. (2012). Annual Reports 2011-2012. Kathmandu, Nepal: Ministry of Forests and Soil Conservation, Department of National Parks and Wildlife Conservation (DNPWC).

Hanemann, W. M. (1984). Welfare evaluations in contingent valuation experiments with discrete responses. American Journal of Agricultural Economics, 66(3), 332-341.

Hanemann, W. M. (1989). Welfare evaluations in contingent valuation experiments with discrete response data: reply. American Journal of Agricultural Economics, 71(4), 1057-1061.

Herath, G., \& Kennedy, J. (2004). Estimating the economic value of Mount Buffalo National Park with the travel cost and contingent valuation models. Tourism Economics, 10(1), 6378. 
IUCN. (2005). Benefits beyond boundaries: Proceedings of the Vth IUCN World Park Congress, Gland, Switzerland.

IUCN, \& UNEP-WCMC. (2012). The World Database on Protected Areas (WDPA). Retrieved 5 December 2013, from United Nations Environmental Program - World Conservation Monitoring Centre (UNEP-WCMC) (http://www.wdpa.org/Statistics.aspx)

Laarman, J. G., \& Gregersen, H. M. (1998). Pricing policy in nature-based tourism. Tourism Management, 17(4), 247-254.

Lesser, J. A., Dodds, D. E., \& Zerbe, R. O. (1997). Environmental economics and policy. New York, USA: Addison-Wesley.

Lindberg, K., \& Huber Jr, R. M. (1993). Economic issues in ecotourism management. Ecotourism: a guide for planners and managers, 82-115.

minube. (2014). The 35 Most Amazing National Parks on Earth. Hoffington Post. Available at http://www.huffingtonpost.com/minube/the-35-most-amazing-natio_b_5439362.html, Accessed on 15 June 2014. Retrieved from

Mitchell, R. C., \& Carson, R. T. (1989). Using surveys to value public goods: the contigent valuation method. Washington DC: Resources for the Future.

Mmopelwa, G., Kgathi, D. L., \& Molefhe, L. (2007). Tourists' perceptions and their willingness to pay for park fees: A case study of self-drive tourists and clients for mobile tour operators in Moremi Game Reserve, Botswana. Tourism Management, 28(4), 1044-1056. doi: 10.1016/j.tourman.2006.08.014

Naidoo, R., \& Adamowicz, W. L. (2005). Biodiversity and nature-based tourism at forest reserves in Uganda. Environment and Development Economics, 10(2), 159-178. doi: 10.1017/S1355770X0400186X

Naughton-Treves, L., Holland, M. B., \& Brandon, K. (2005) The role of protected areas in conserving biodiversity and sustaining local livelihoods. Vol. 30. Annual Review of Environment and Resources (pp. 219-252).

Nepal Rastra Bank. (2014). Foreign Exchange Rates. Available at: http://nrb.org.np/fxmexchangerate1.php [Accessed on 21 September 2014].

Nyaupane, G. P., \& Poudel, S. (2011). Linkages among biodiversity, livelihood, and tourism. Annals of Tourism Research, 38(4), 1344-1366. doi: 10.1016/j.annals.2011.03.006 
R Development Core Team. (2011). R: A Language and Environment for Statistical Computing. Vienna, Austria: R Foundation for Statistical Computing.

Ransom, K. P., \& Mangi, S. C. (2010). Valuing recreational benefits of coral reefs: The case of Mombasa Marine National Park and Reserve, Kenya. Environmental Management, 45(1), 145-154. doi: 10.1007/s00267-009-9402-9

Reynisdottir, M., Song, H., \& Agrusa, J. (2008). Willingness to pay entrance fees to natural attractions: An Icelandic case study. Tourism Management, 29(6), 1076-1083. doi: 10.1016/j.tourman.2008.02.016

Skanavis, C., \& Sakellari, M. (2011). International tourism, domestic tourism and environmental change: Environmental education can find the balance. Tourismos, 6(1), 233-249.

Tapsuwan, S., Burton, M., \& Perriam, J. (2010). A multivariate probit analysis of willingness to pay for Cave conservation: A case study of Yanchep National Park, Western Australia. Tourism Economics, 16(4), 1019-1035.

Thur, S. M. (2010). User fees as sustainable financing mechanisms for marine protected areas: An application to the Bonaire National Marine Park. Marine Policy, 34(1), 63-69. doi: 10.1016/j.marpol.2009.04.008

Venkatachalam, L. (2004). The contingent valuation method: A review. Environmental Impact Assessment Review, 24(1), 89-124. doi: 10.1016/S0195-9255(03)00138-0

Venter, O., Fuller, R. A., Segan, D. B., Carwardine, J., Brooks, T., Butchart, S. H. M., . . . Watson, J. E. M. (2014). Targeting Global Protected Area Expansion for Imperiled Biodiversity. PLoS Biology, 12(6). doi: 10.1371/journal.pbio.1001891

Walpole, M. J., \& Goodwin, H. J. (2000). Local economic impacts of dragon tourism in Indonesia. Annals of Tourism Research, 27(3), 559-576. doi: 10.1016/S01607383(99)00088-2

Walpole, M. J., Goodwin, H. J., \& Ward, K. G. R. (2001). Pricing policy for tourism in protected areas: Lessons from Komodo National Park, Indonesia. Conservation Biology, 15(1), 218-227. doi: 10.1046/j.1523-1739.2001.99231.x

Wells, M. P. (1993). Neglect of biological riches: the economics of nature tourism in Nepal. Biodiversity and Conservation, 2(4), 445-464. doi: 10.1007/BF00114046

Wells, M. P., \& McShane, T. O. (2004). Integrating protected area management with local needs and aspirations. Ambio, 33(8), 513-519. 
Wen, Z. (1997). China's domestic tourism: Impetus, development and trends. Tourism Management, 18(8), 565-571.

White, P. C. L., \& Lovett, J. C. (1999). Public preferences and willingness to pay for nature conservation in the North York Moors National Park, UK. Journal of Environmental Management, 55(1), 1-13. doi: 10.1006/jema.1998.0250

Whitelaw, P. A., King, B. E. M., \& Tolkach, D. (2014). Protected areas, conservation and tourism - financing the sustainable dream. Journal of Sustainable Tourism, 22(4), 584603. doi: 10.1080/09669582.2013.873445

World Bank. (2014). Data. Available at: http://data.worldbank.org/ [Accessed on 3 October 2014]. 


\section{Tables}

Table 1 Number of visitors to CNP by fiscal year and visitor category

\begin{tabular}{lccccc}
\hline & & & \multicolumn{3}{c}{ CNP visitors by category } \\
\cline { 4 - 6 } Fiscal year* & Total PA visitors & CNP Visitors & NSAF & SAF & Domestic \\
\hline \multirow{2}{*}{$2007-2008$} & 291,040 & $105,844(36 \%)$ & $67,688(64 \%)$ & $8,056(8 \%)$ & $30,100(28 \%)$ \\
$2008-2009$ & 349,195 & $118,685(34 \%)$ & $70,988(60 \%)$ & $12,591(11 \%)$ & $35,106(29 \%)$ \\
$2009-2010$ & 381,789 & $115,181(30 \%)$ & $72,973(63 \%)$ & $10,899(10 \%)$ & $31,309(27 \%)$ \\
\hline
\end{tabular}

* Fiscal year in Nepal runs from $16^{\text {th }}$ July to $15^{\text {th }}$ July

Source: Annual reports (DNPWC, 2008, 2009, 2010). 
Table 2 Variable description and summary statistics by visitor category

\begin{tabular}{|c|c|c|c|c|}
\hline Variable & Description & $\begin{array}{l}\text { NSAF } \\
\text { Mean (STD) }\end{array}$ & $\begin{array}{l}\text { SAF } \\
\text { Mean (STD) }\end{array}$ & $\begin{array}{l}\text { Domestic } \\
\text { Mean (STD) }\end{array}$ \\
\hline Willingness to Pay & $\begin{array}{l}\text { Binary variable: willing to pay the fee mentioned in the questionnaire }= \\
1, \text { not willing to pay }=0 .\end{array}$ & $0.347(0.477)$ & $0.583(0.498)$ & $0.475(0.506)$ \\
\hline Bid value $^{13}$ & $\begin{array}{l}\text { Ratio scale: the bid amount ranged from } 15 \text { to } 40 \text { at an interval of US\$ } \\
5 \text { for NSAF. }\end{array}$ & $26.37(8.444)$ & $12.4(4.205)$ & $198(85.448)$ \\
\hline Age & Ratio scale: visitor's age in year & $31.2(12.934)$ & $37.1(11.547)$ & $32.8(8.285)$ \\
\hline Gender & Dummy variable: male $=1$, female $=0$ & $0.383(0.487)$ & $0.646(0.483)$ & $0.6(0.496)$ \\
\hline Member & $\begin{array}{l}\text { Dummy variable: if the visitor is a member of environmental } \\
\text { group/society }=1 \text {, otherwise } 0 .\end{array}$ & $0.225(0.419)$ & $0.229(0.425)$ & $0.525(0.506)$ \\
\hline Education $^{14}$ & $\begin{array}{l}\text { Ordinal scale }(1 \text { to } 10) \text {, where } 1=\text { no schooling; } 2=<7 \text { th grade } ; 3=7 \text { th } \\
\text { grade; } 4=\text { some high school }(8-11 \text { grade }) ; 5=\text { high school; } 6=\text { college } \\
\text { but no degree; } 7=\text { associate/vocational degree; } 8=\text { Bachelor's degree; } \\
9=\text { Master's degree; and } 10=\text { Doctorate degree. }\end{array}$ & $7.56(1.649)$ & $8.21(1.320)$ & $5.3(0.966)$ \\
\hline Visit experience & $\begin{array}{l}\text { Ordinal scale ( } 1 \text { to } 10) \text { : visitors rated their overall visit experience to } \\
\text { Chitwan National Park in a scale of } 1 \text { (not positive at all) to } 10 \text { (very } \\
\text { positive). }\end{array}$ & $8.32(1.376)$ & $7.31(1.881)$ & $7.88(1.411)$ \\
\hline Visit to other parks & Dummy variable: visited other parks in Nepal = 1, otherwise 0 & $0.167(0.374)$ & $0.125(0.334)$ & \\
\hline $\begin{array}{l}\text { Environmental } \\
\text { concern }\end{array}$ & $\begin{array}{l}\text { Index variable. Respondents were asked to rate three statements about } \\
\text { wildlife disturbance, solid waste and water pollution in and around the } \\
\text { park on a 5-point scale from strongly disagree (1) to strongly agree (5). }\end{array}$ & $9.77(2.770)$ & $11(2.488)$ & $12.7(2.418)$ \\
\hline Day & Ration scale: days spent at Chitwan National Park & $2.64(0.655)$ & $2.65(1.062)$ & $2.82(1.107)$ \\
\hline $\mathrm{N}$ & Number of observations & 222 & 48 & 40 \\
\hline
\end{tabular}

${ }^{13}$ The bid amount for South Asian (US\$7.5, 10, 12.5, 15, 17.5, \& 20) and domestic visitors (NRs 100, 150, 200, 250, 300, \& 350) were different.

${ }^{14}$ Education is measured differently for three categories of visitors. For South Asians: $1=$ no schooling, $2=$ up to $6^{\text {th }}$ grade, $3=7^{\text {th }}$ grade, $4=8-11$ th grade, $5=$ High School, $6=$ some college, $7=$ Associate degree, $8=$ Bachelors, $9=$ Masters, $\& 10=$ Doctorate. For Nepalese: $1=i l l i t e r a t e, 2=$ up to $8^{\text {th }}$ grade, $3=9-10^{\text {th }}$ grade, $4=$ School Leaving Certificate, $5=10+2$ level, $6=$ Bachelors, $7=$ Masters, $\& 8=$ Doctorate. 
Table 3 Response profile for candidate entry fees and their observed and expected proportions of acceptance by visitor category

\begin{tabular}{cccc}
\hline $\begin{array}{c}\text { Candidate entry fee } \\
\text { (US\$) }\end{array}$ & $\begin{array}{c}\text { No. of questionnaires } \\
\text { offered }\end{array}$ & $\begin{array}{c}\text { No. of questionnaires } \\
\text { accepted }\end{array}$ & $\begin{array}{c}\text { Proportions } \\
\text { accepted }\end{array}$ \\
\hline NSAF & & 25 & \\
15 & 45 & 15 & 0.556 \\
20 & 39 & 13 & 0.385 \\
25 & 37 & 12 & 0.351 \\
30 & 42 & 8 & 0.286 \\
35 & 29 & 4 & 0.276 \\
40 & 30 & & 0.133 \\
\hline SAF & & 10 & \\
7.5 & 12 & 7 & 0.833 \\
10 & 10 & 5 & 0.700 \\
12.5 & 9 & 3 & 0.556 \\
15 & 6 & 1 & 0.500 \\
17.5 & 6 & 1 & 0.167 \\
20 & 5 & & 0.200 \\
\hline Domestic & & 7 & \\
1.38 & 11 & 5 & 0.636 \\
2.07 & 8 & 3 & 0.625 \\
2.76 & 6 & 2 & 0.500 \\
3.45 & 6 & 1 & 0.333 \\
4.14 & 5 & 1 & 0.200 \\
4.83 & 4 & & 0.250 \\
\hline
\end{tabular}

* Exchange rate US $\$ 1=$ NRs 72.46 
Table 4 Logit regression results of Willingness to Pay for increased entry fee with $95 \%$ confidence interval (CI) for coefficient estimates by visitor category

\begin{tabular}{|c|c|c|c|c|c|c|}
\hline \multirow[b]{2}{*}{ Variable } & \multicolumn{2}{|c|}{ NSAF } & \multicolumn{2}{|c|}{ SAF } & \multicolumn{2}{|c|}{ Domestic } \\
\hline & Coefficient (SE) & $95 \% \mathrm{CI}$ & Coefficient (SE) & $95 \% \mathrm{CI}$ & Coefficient (SE) & $95 \% \mathrm{CI}$ \\
\hline (Intercept) & $-2.456(1.631)$ & {$[-5.653,0.742]$} & $-5.032(5.020)$ & {$[-14.870,4.806]$} & $-4.977(4.929)$ & {$[-14.637,4.683]$} \\
\hline Bid value & $-0.081 * * *(0.020)$ & {$[-0.121,-0.042]$} & $-0.279 * *(0.130)$ & {$[-0.534,-0.024]$} & $-0.025 * *(0.011)$ & {$[-0.045,-0.004]$} \\
\hline Age & $-0.011(0.014)$ & {$[-0.039,0.017]$} & $-0.082(0.059)$ & {$[-0.198,0.035]$} & $0.159 *(0.088)$ & {$[-0.012,0.331]$} \\
\hline Gender & $0.235(0.330)$ & {$[-0.413,0.882]$} & $2.359 *(1.357)$ & {$[-0.300,5.018]$} & $-1.087(1.053)$ & {$[-3.151,0.977]$} \\
\hline Member & $1.302 * * *(0.392)$ & {$[0.534,2.070]$} & $-0.534(1.165)$ & {$[-2.817,1.748]$} & $-1.507(1.081)$ & {$[-3.625,0.612]$} \\
\hline Education & $0.230 * *(0.110)$ & {$[0.015,0.446]$} & $0.466(0.492)$ & {$[-0.499,1.429]$} & $0.209(0.516)$ & {$[-0.801,1.220]$} \\
\hline Visit experience & $0.367 * * *(0.129)$ & {$[0.113,0.621]$} & $1.361 * * *(0.477)$ & {$[0.426,2.297]$} & $0.842 * *(0.386)$ & {$[0.086,1.598]$} \\
\hline Visit to other parks & $-0.013(0.414)$ & {$[-0.824,0.799]$} & $-0.345(2.681)$ & {$[-5.599,4.909]$} & & \\
\hline Environmental concerns & $-0.105 *(0.061)$ & {$[-0.225,0.015]$} & $-0.282(0.284)$ & {$[-0.838,0.275]$} & $-0.131(0.255)$ & {$[-0.631,0.368]$} \\
\hline $\mathrm{N}$ & 222 & & 48 & & 40 & \\
\hline Log-likelihood & -121.3 & & -15.99 & & -17.17 & \\
\hline AIC & 260.6 & & 49.99 & & 50.33 & \\
\hline
\end{tabular}


Table 5 Summary of responses to follow-up WTP questions among NSAF visitors*

$\begin{array}{ll}\text { Description } & \text { Frequency }\end{array}$

Reasons for willing to pay increased entry fee $(n=32)$

The park offers the opportunity to see unique wildlife [for example: Rhinoceros]

The park offers the opportunity to experience natural environment (vegetation, landscapes, rivers etc.)

Current park entry fee (US\$7/day) is too low for the experience the park offers to visitors

To support conservation activities in the park

To support local communities and development activities around the park

Others (such as - support quality tourism, reduce solid waste pollution, to implement eco-friendly projects - solar, maintain Tharu culture)

Reasons for unwilling to pay increased entry fee $(n=47)$

The park is congested or over-crowded

$\begin{array}{ll}\text { The park is polluted (solid waste and water pollution) } & 13\end{array}$

The park facilities (visitor centre, trails, sign posts etc.) are not well maintained 15

The entry permit issue process is too cumbersome 5

The park does not offer the experience for the level of fee proposed 15

Proposed fee is too high for my income $\quad 22$

Others (such as, increased fee will allow access to rich people, while the park should be accessible for all, fee is high compared to average living cost in the area, unlikely to add ecotourism experience, use gradual increase rather than drastic increase on fee, animal cruelty - treating elephants)

* This is based on the responses provided by visitors where they were allowed to choose more than one reasons to the follow-up questions. 
Table 6 Predicted probability of WTP, visitor number and revenue ${ }^{18}$ by entry fee and visitor category along with associated changes in visitors and revenues compared to 2009/10 fiscal year (July 16, 2009 to July 15, 2010)

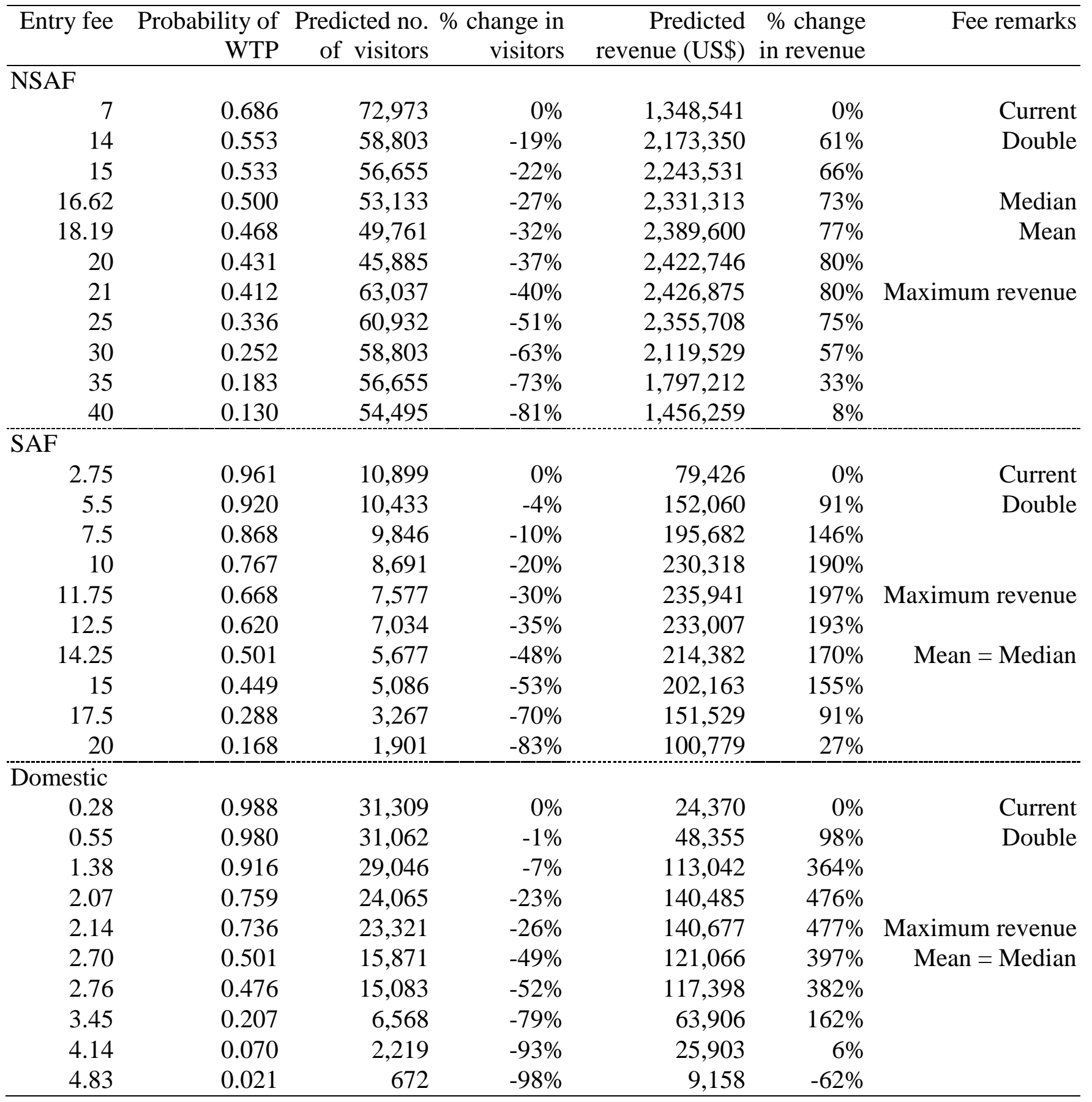

\footnotetext{
${ }^{18}$ Predicted revenue $=$ entry fee $\mathrm{x}$ no. of visitors $\mathrm{x}$ mean no. of days at CNP, which is $2.64,2.65$ and 2.82 for NSAF, $\mathrm{SAF}$ and domestic visitors, respectively.
} 
Figures

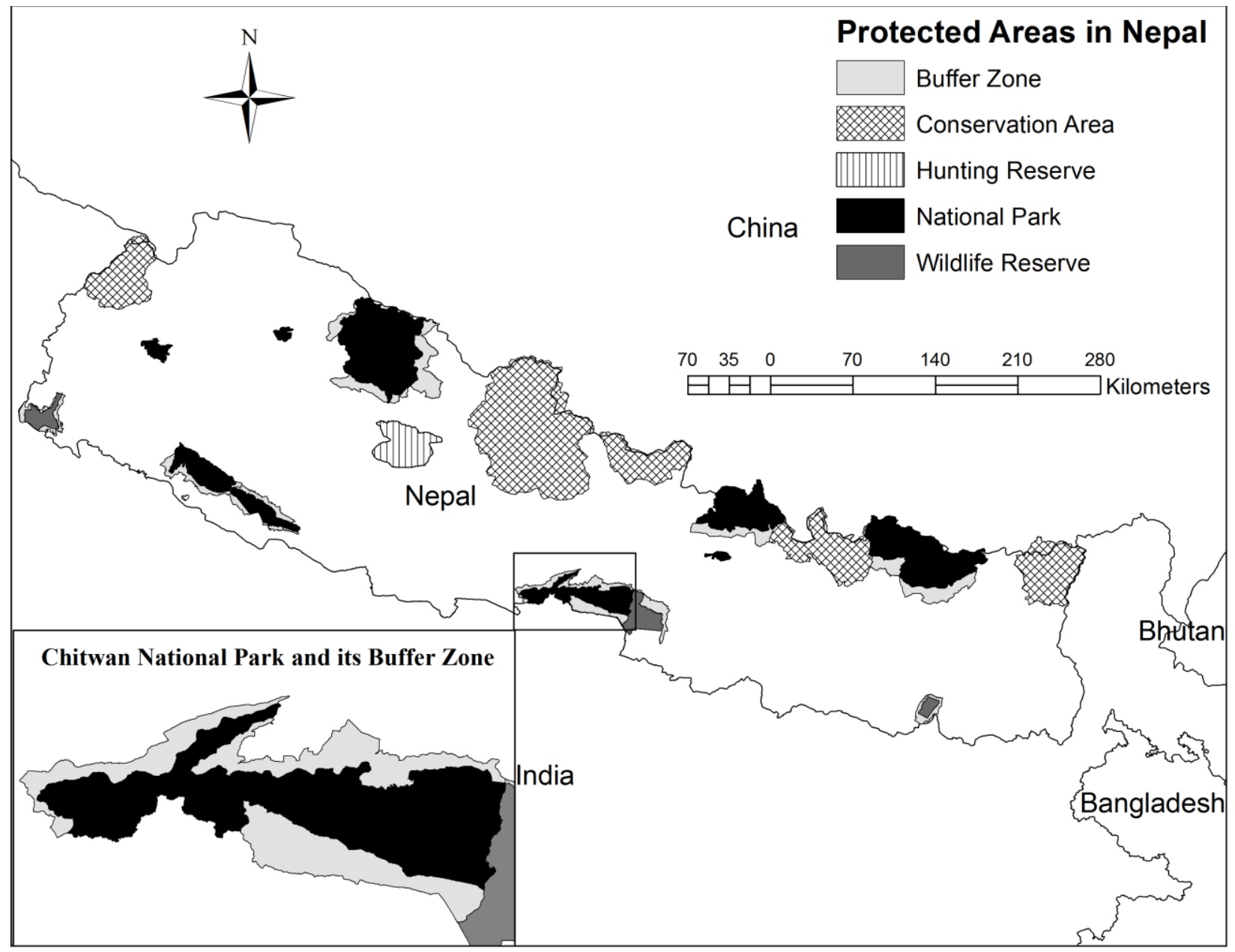

Figure 1 Map of the protected areas in Nepal [Inset: Chitwan National Park and its buffer zone] 


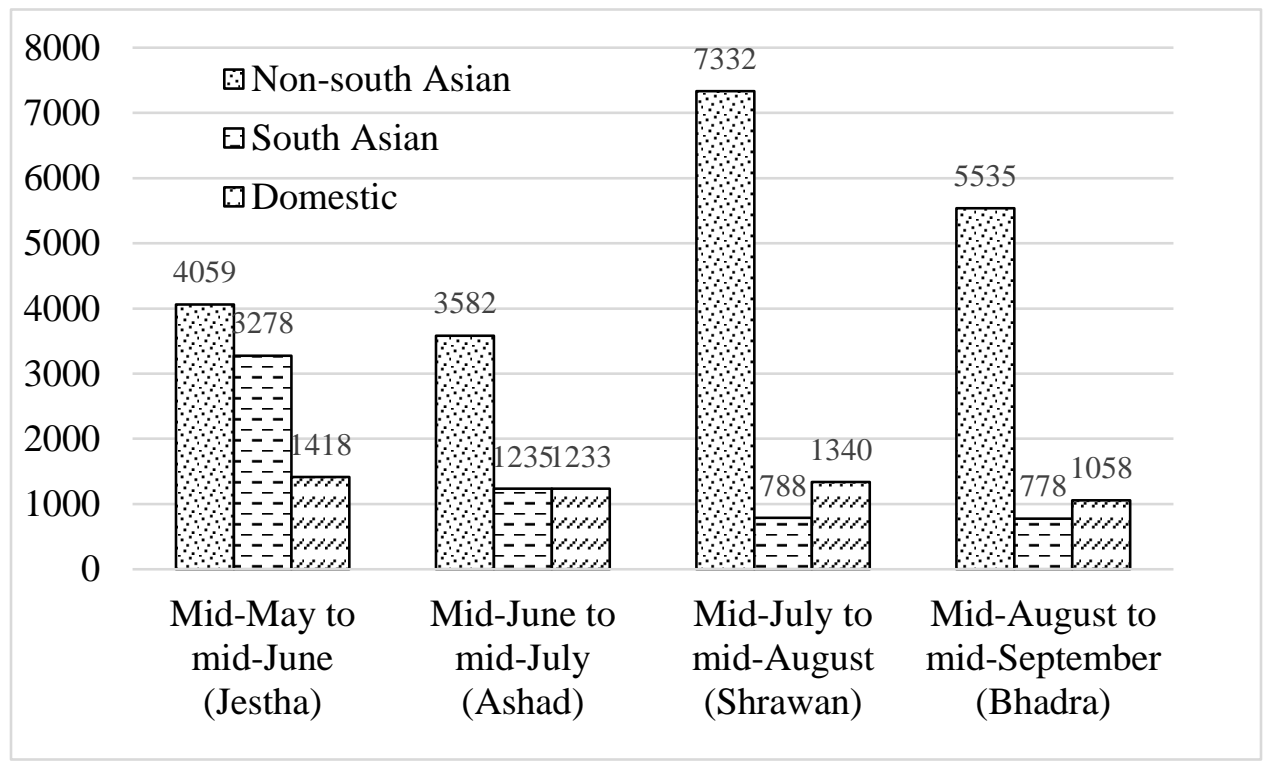

Figure 2 Number of visitors at CNP during the study period (mid-May to mid-Sept, 2011) by Nepali month and visitor category 


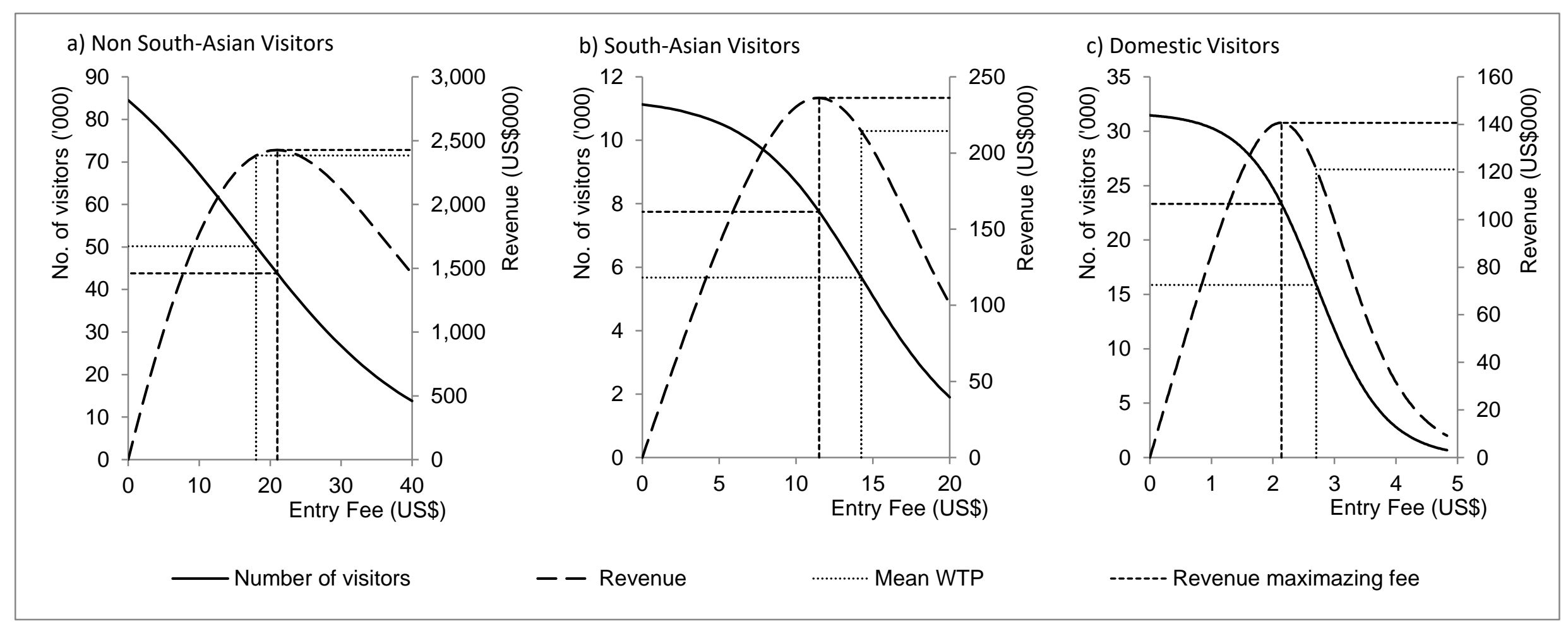

Figure 3 Predicted number of visitors and revenue by level of entry fee (including mean WTP and revenue maximising fee) and visitor category 